\title{
UKRAINIAN HYBRID WAR - QUO VADIS?
}

\author{
Carmen ROTĂRESCU \\ carmenrotarescu@yahoo.com \\ LAND FORCES STAFF, BUCHAREST, ROMANIA
}

\begin{abstract}
Although it is known for a long time, hybrid war taken place in Ukraine under the umbrella of Russian Federation surprised the whole world and produced the greatest worry for humankind's fate since the World War II. The political and military analysts appreciate if the World War III does not come will at least follow a long time of a new cold war. Remembering the hybrid war is not declared, can be prolonged in time and the adversary is unknown, thus neither the aggressor state, it is hard to settle which are the countermeasures and how should be act when this clever adversary attacks you using hostile propaganda, to the limit of trick and war perfidy (the first is allowed as method of war, the latter is not), influences the political decision-makers by blackmail, military, economic and energetic deterrence or nuclear bombardments and undergoes subversive, clandestine actions and particularly it is hard to predict their consequences.
\end{abstract}

\section{Keywords}

Hybrid war, cold war, World War III, conflict, international law

\section{Conflicts' qualification}

The International Humanitarian Law [1] is a branch of public international law and in regard to our definition it comprises a set of principles and customary and/or conventional norms applicable in time of international or non-international armed conflict meant to protect persons who do not participate or stop to participate to hostilities, to limit the methods and means used by combatants, to significantly diminish the consequences of the armed conflicts and to provide the future of the humankind. Therefore, the International Humanitarian Law is called to protect the human being in situation of armed conflict and to preserve the material and moral values of the humanity, and these are the reasons it must be acknowledged and promoted since peacetime and respected and applied on time of armed conflict.

In order to identify the provisions of the International Humanitarian Law following to be applied in times of armed conflict it is necessary to be identified the type of conflict. In Article 1 paragraph 4 of the Additional Protocol I to the Geneva Conventions (1949), it is provisioned: "the armed conflicts wherein the people fight against the colonial domination, foreign occupation or racist regimes should be considered international conflicts" [2]. 
To the non-international armed conflict, respectively intern there are applicable the provisions of Article 3 common to the Geneva Conventions in 1949 and where are applied the conditions also requested in Additional Protocol II to this Convention. The mentioned norms can be completed, where is the case, with customary law rules [3], applicable along this type of armed conflict [4].

Although the juridical instruments of International Humanitarian Law (IHL) do not define the armed conflict, the gap seems to be solved by the international jurisprudence by Case IT-94-1-AR72, prosecutor versus Tadic, paragraph 70 [5]. The intern armed conflict is not defined by Article 3 common for all four Geneva Conventions (1949); its definition is more than necessary under the circumstances when for intern tensions and disturbances there are applicable the human rights. Also in this situation the solution is given by jurisprudence by the decision of International Criminal Tribunal for Rwanda, for Case ICTR 96-4, prosecutor versus Jean Paul Akayesu, paragraph 625, 2nd of September 1998 [6].

The ,armed conflict” term is preferred to the term of war following the prohibition of war by Briand Kellog Pact in 1928 and then by United Nations Charter, still, despite the use of the term became improper, it is equally used as the ,armed conflict" term. Along the international and non-international armed conflict we also observe other types of conflicts: de-structured or identitary armed conflict, war against terror, internationalized armed conflict etc. [7].

For our study it is interesting the internationalized armed conflict characterized by the fact it starts as intern conflict and afterwards internationalizes following the supported offered to the insurgent forces by other states and/or the direct intervention of a state or many states. The typical example of the internationalized conflict is the one from Nicaragua which became the subject of jurisprudence in the case Nicaragua versus USA [8] and initiated effective control test over the military and paramilitary operations, test proposed by the International Court of Justice. This test was considered inconclusive by the Appeals Chamber of the International Criminal Tribunal for the former Yugoslavia because it does not settles with certainty what it is understood by this effective control (the settlement of a state guilt regarding the actions of insurgents from another state) and that proposed another type of test so-called global (or overall) test [9], including different criteria of overall control. This test do not aim just the conflict's qualification but also the responsibility of a third state involved in the development of some insurgent forces fighting against their own state, actions with decisive role in planning, conductment and execution of military actions of insurgent forces, including their financing [10]. A type of internationalized conflict is the hybrid conflict, but hybrid war is the used term.

\section{Hybrid War}

Although we choose hybrid war expression, hybrid word can also accompany terms as conflict or threat, as the theoreticians and practitioners in the international law field appreciate the content of the undergoing actions, their ampleness and the participant subjects, there are contrary opinions along them as regards the terms to be used, similar situation as for the asymmetric word accompanying the same terms..

Based on the results obtained after the scientific initiative as the understanding of what means hybrid war in our perception, this is threat, asymmetric type intervention, military strategy combining the elements of conventional, civil war with terrorist, cyber, informational, psychological, media, electronic, meteorological, nuclear, biological, chemical as well as other nature wars [11].

In the opinion of Robert M. Gates, US Secretary of Defense, "the hybrid war is the sum of two legal and illegal, conventional and non-conventional, regulated and irregular opposed forces in order to produce an attack" [12].

In regard to NATO, the hybrid war term refers to "a large area of hostile actions, 
wherein the military force represents just a small part and wherein are executed and oriented as part of flexible strategies with long termed goals" [13].

Referring to hybrid war, the Chief of General Staff of the Russian Armed Forces and the prime/deputy of ministry of defense, general Valeri Gherasimov have shown in an article published in 2013, in VPK publication, that ,the methods of war changed and they recently involved the use of political, economic, informational, humanitarian as well as other non-military measures to which there are added the involvement of local population as a fifth column and of the under-covered armed forces" [14]. In regard to Gherasimov, the threshold between peace and war can be easily surpassed as the official mobilization does not intervene but when the war was declared and it can take place in utmost unobserved conditions.

In our regard, hybrid war is more perfidious than the war of terrorists because as long as the terrorists claim their actions, for the hybrid wars the combatants are not known, do not wear uniforms or other distinctive signs. They are the so-called "little green people" hidden among the civil population disrespecting the provisions of international law, implicitly the humanitarian law provisions and whom, in order to reach some political, economic, social, territory etc. goals, simultaneously use weapons and systems of conventional and other nature armaments. It must be noticed that the actions of these combatants do not limit to the military type ones and they are able to undergone even before the proper triggering of a conflict. Therefore, we remember the actions to destabilize or dismantle some institutions, to infiltrate into the minority population under the pretext of its protection, to deter, manipulate and influence it etc. These actions are meant to create a space of influence and to open the ways necessary to reach the aimed goals and are executed by "little green people, before the little green people" [15]. The goal of some manoeuvres as the ones shown above is to provoke social discontents possible to lead to civil wars, to intimidate by economic, energetic etc. views. The phases of these consist in: "media and informational war for the defamation and legitimizing power plants, followed amid discontent citizens, to issue claims of triggering these manoeuvres" [16].

The most popularized example of hybrid war was represented by Hezbollah actions in 2006 meanwhile the Lebanon war when Hezbollah put to the test the Israeli armed forces by the actions they did by executing "surprise" manoeuvres from hideouts and underground tunnels combined with conventional infantry actions executed in Lebanese villages and using diversified weapons including missiles (anti-maritime transportation cruise missile). Despite their modern capabilities, the actions of the Israeli armed forces were cancelled by Hezbollah fighters.

The hybrid war takes also the form of actions undergone by resistance movements to overthrow a government, militants of these movements and actions being supported financially illegally from other countries. In this regard, we have the example in 1986 of Nicaragua versus US judged by the International Court of Justice (ICJ), which ruled in favor of Nicaragua forcing the US to grant compensation. As grounds ICJ ruling found that the US had violated international law by supporting the Contras forces in their actions carried out against the Government of Nicaragua [17]. Based on previous evidence, the Court found that the US had violated the principles and norms of international law and intervened in the internal affairs of another state violated its sovereignty when trained, equipped and funded Contras forces and encouraged, supported and helped them in undergoing their military and paramilitary activities conducted against Nicaragua.

In regard to the judgment of the Court an armed attack includes: "regular armed forces across an international border, but also sending by or on behalf of a State of armed troops, irregular forces or mercenaries, which carry out military action 
against another State of such gravity and scale comparable to an attack carried out by regular armed forces" [18].

The operations undergone by the rebel forces (pro-Russian separatists) from Lugansk, Doneţk and Mariupol, in Ukraine proved they have operational capacity and particular military training that could endanger Kiev which is impossible without external support for training, endowment and acting, provided by the Russian Federation [19].

The "undercover" actions of Russian Federation did not consist only in the military and financial support given to the Ukrainian separatists; they were also political and economic. The Russian Federation knows the supremacy of "Their Highness, the Money" and employed as consultants different occidental parliamentarians, bought diverse companies, compromised and blackmailed Westerner specialists working in Moscow, offered energetic support in exchange of some facilities or fulfilment of some conditions, even reaching to use "organized crime as an instrument" [20].

Among the Russian Federation's favourite means and methods of war there are espionage, applied before the Ukrainian conflict start and the use of mass media, as the use of televisions and release of a radio post "Sputnik news" is about to operate since 2015 in 130 cities from 34 countries all over the world and has offices in Bucharest, Kishinev, Kiev, Minsk and Belgrade, Beijing, Washington and Cairo, in 30 languages and will emit continuous. The Russian Federation understands the value and power of information received and transmitted did not limited to the establishment of a radio station and some websites, there were also purchased some newspapers in the country or abroad, some of which failed, but also developed a truly global media network, thus using a wider range of media manipulation of the population, for misinforming and its influence to ensure political control of those in power [21]. Moreover, the Russians have "the concept of "political technology» which consists in spreading false information, assiduous cultivation of a variety of conspiracy theories, extortion and destruction of compromising materials published by the opposition, but also covered actions such as creating false matches opposition, independent NGOs or false independent publications, which, under the apparent respectability, to serve the interests of political masters. Also in this concept talk about handling the economy and markets and strict control on intelligence, law enforcement bodies and the judiciary, which can always be pitting against real or appointed opponents" [22].

\section{International Relations to the Conflict in Ukraine}

The annexation of Crimea, the hybrid war waged by Russia in Ukraine, equipping with drone Orlan-10 type warheads capable of carrying nuclear warheads at distances and the staff of deployed Russian troops in the Crimea (to whom will be allocated over $\$ 9$ billion, since 2020) [23], briefly, the use of conventional weapons and systems of weapons combined to nonconventional weapons, practices infringing the international law principles and norms as a whole and the international humanitarian law particularly determined a series of international reactions.

Germany has taken steps to change its military strategy. This year representatives of the German government and armed forces analyse the requisite amendments to the current German military strategy in the context of hybrid warfare used by Russian in Ukraine and the existing geopolitical challenges [24]. It also examines the need for a new US military strategy that meets the needs of counteractions hybrid war [25].

Sweden and Finland, NATO nonmember states, concerned about the manner of intervention of Russia in Ukraine, but also more active presence of the Russian fleet in the Baltic Sea, decided to establish a joint naval force, with defensive purpose, operating in situation of war and to become operational by 2023 [26].

British MI5 intelligence service employs in analysts positions Russian-speaking persons who must have spent at least eight of the last 
ten years in the UK, have at least one British parent and are very discreet about the activities to be undertaken. The selection process is very rigorous and will take about 9 months. The activities of analysts will consist of telephone interception analysis and synthesis of information contained in various documents in order to obtain data and information on current and future intentions and actions of the Russian Federation [27].

Amid tensions with NATO for the annexation of Crimea and the situation in Ukraine, the Russian President V. Putin signed a decree dated 02.01.2015 which allowed foreign nationals, aged between 18 and 30 years, to employ in the Russian armed forces for a salary estimated at 400 euros. They must know the Russian language, have no criminal record and sign an employment contract for a period of 5 years. They expect the main candidates for recruitment from Belarus, Armenia, Kyrgyzstan, Transnistria and Abkhazia [28]. Military analysts are concerned that Moscow needs more soldiers, given that currently has over 3.25 million active and reserve personnel, 46.8 citizens fit for military service and 300 foreign and is considered the fourth largest armed forces in the world after China, India and South Korea [29].

Also, in 2015, the Russian Federation intends to equip the Russian Navy with 50 ships, including six Grigorovici class frigates, an unspecified number of new or upgraded military submarines including six hybrid (diesel-electric) Varşavianka class submarines and nuclear-powered submersible type Borei, which will deploy in the Black Sea [30].

Vladimir Evseev [31] said that the Russian Federation is considering a number of military objectives that will neutralize using different types of weapons among which include the future of NATO command centre that will be accommodated in Romania. Furthermore, it claimed that Russian forces will act and stave Romanian navy, because Romania cannot create an offensive force [32].

\section{Instead of Conclusions, Reflections and a Plea for Humanity}

In 2014, the world commemorated the 100th anniversary of the outbreak of World War I and from the world geopolitical situation analysis we easily can see that it has learned nothing of past experiences and not channelled all the strength and energy to save Earth from the devastating effects of armed conflict, but is about to put a far greater danger than was subjected to the two big wars, if not to destroy it [33].

Seeing what is happening in the world today is natural to raise you a series of rhetorical questions: What do we have used many principles and norms of international law if they are openly violated? Who will use the Earth's destruction by nuclear weather, chemical or biological weapons? Who will be able to use an impoverished land resources and affected environment, at best, over many years?

What happens particularly in Ukraine, Syria or Iraq are warning signs that the international security situation is far from ensuring safe environment that is needed for humanity development and progress, even for a peaceful and decent life.

Are we really close to the World War III, is it already begun since the conflict in Ukraine or the first major action of the Islamic state, or is it just a trick of the media war, used as a weapon of handling of international public opinion? [34]. Have it begun a new era of cold war?

Hopefully we will have lucidity to look beyond of pride, which is also the first sin before a fall and hope not get as Einstein said, "I do not know with what weapons will be fought in World War III, but certainly the fourth will be fought in with sticks and stones" [35]. Pericles appreciated ,,it is not important to forecast the future but to be prepared for it", but how to forecast which will be the consequences of a hybrid answer in a hybrid war if the nuclear threat comes as a stake? Thus, it is preferred to be taken all the necessary and possible measures to prevent a hybrid war but to engage in its counteraction. 


\section{Aknowledgement}

This work was possible with the financial support of the Sectoral Operational Programme for Human Resources Development 2007-2013, co-financed by the European Social Fund, under the project number POSDRU/159/1.5/S/138822 with the title "Transnational network of integrated management of intelligent doctoral and postdoctoral research in the fields of Military Science, Security and Intelligence, Public order and National Security - Continuous formation programme for elite researchers - «SmartSPODAS»".

\section{References}

1. Definiţia Dreptului Internaţional Umanitar şi locul său în ordinea legală internaţională, http://www.crucearosie.ro/uploads/images/Conventia\%20de\%20la\%20Geneva\%20pdfuri/De finitia $\% 20 \mathrm{DIU} \% 20 \mathrm{si} \% 201 \mathrm{ocul} \% 20 \mathrm{sau} \% 20 \mathrm{in} \% 20$ ordinea $\% 20$ legala $\% 20$ internationala.pdf, (accessed April 4, 2015 (Apud: Hans-Peter Gasser, "International Humanitarian Law An introduction", in: Hans Haug, Humanity for all, Henry Dunant Institute, 1993), 509: "International humanitarian law can be defined as the totality of international conventional or customary rules regulating the humanitarian issues as direct result of international and national armed conflict. By humanitarian reasons, they restrict the right of parties involved in an armed conflict to use means and methods of war and intends to protect persons and goods into the conflict".

2. See Protocol Additional to the Geneva Conventions of 12 August 1949, and relating to the Protection of Victims of International Armed Conflicts (Protocol I), 8 June 1977, https://www.icrc.org/ ihl/INTRO/470, (accessed March 3, 2015).

3. International Justice Court Statute, Art. 38 line1 let. c. "The Court has the missions to solve in conformity to the international law the disputes complied to it and will apply: ... the international customary law as proof of overall accepted", https://jurisdictie. wordpress.com/2013/12/02/statutul-curtii-internationale-de-justitie-in-limba-romana/, (accessed March 28, 2015.

4. Jean Marie Henckaerts, Studiul privind dreptul internaţional umanitar cutumiar, contribuţie la inţelegerea şi respectarea dreptului in conflictele armate, https://www.icrc.org/ eng/assets/files/other/rom-irrc 857 henckaerts.pdf, (accessed March 03, 2015).

5. As the Apeal Court settled "an armed conflict is indifferently if is undergone among the armed forces of two states or manifest as prolonged violence among the governmental authorities and organized armed groups or among these groups and the state" (See: Prosecutor v. Dusko Tadic, Case No. IT-94-1-AR72, Decision on the Defence Motion for Interlocutory Appeal on Jurisdiction, 2 October 1995 (concerning "Decision for Tadic case"), para. 70, http://www.icty.org/x/cases/tadic/acdec/en/51002.htm, (accessed April 5, 2015).

6. "It suffices to recall that an armed conflict is distinguished from internal disturbances by the level of intensity of the conflict and the degree of organization of the parties to the conflict. Under Additional Protocol II, the parties to the conflict will usually either be the government confronting dissident armed forces, or the government fighting insurgent organized armed groups. The term, armed forces' of the High Contracting Party is to be defined broadly, so as to cover all armed forces as described within national legislations". See: The Prosecutor versus Jean-Paul Akayesu, Case No. ICTR-96-4-T, http://www.unictr.org/sites/unictr.org/files/case-documents/ictr-96-4/trial-judgements/en/ 980902.pdf, (accessed April 3, 2015), 156.

7. Jarka Beatrice Onica, Drept internaţional umanitar - Note de curs, (Bucharest: Universul Juridic Publishing House, 2010), 18-25. 
8. Sea: International Court of Justice, Case Concerning Military and Paramilitary Activities in and against Nicaragua, $27^{\text {th }}$ of June 1986, http://www.icj-cij.org/docket/files/ 70/6503.pdf, (accessed April 4, 2015).

9. Celine Tran, La responsabilité internationale de l'Etat pour le fait d'acteurs non étatiques: approche différenciée de deux juridictions internationales, $30^{\text {th }}$ of May 2011, http://m2bde.u-paris10.fr/content/la-responsabilit $\% \mathrm{C} 3 \% \mathrm{~A} 9$-internationale-de-1\%E2\%80\% 99etat-pour-le-fait-d $\% \mathrm{E} 2 \% 80 \% 99$ acteurs-non- $\% \mathrm{C} 3 \% \mathrm{~A} 9$ tatiques-approche-d0?destination $=$ node $\% 2 \mathrm{~F} 2232$, (accessed April 5, 2015).

10. Sea: Prosecutor v. Dusko Tadic, Case No. IT-94-1-AR72 para 132-145, http://www.icty.org/x/cases/tadic/acdec/en/51002.htm, (accessed April 5, 2015).

11. For details on the definition of hybrid conflict, see: Glenn W. Russell, Thoughts on "Hybrid" Conflict, http://smallwarsjournal.com/blog/journal/docs-temp/188-glenn.pdf; United States Government Accountability Office, Hybrid Warfare, 10 septembrie 2010, http://www.gao.gov/assets/100/97054.html; Petri Huovinen, Hybrid Warfare - Just a Twist of Compound Warfare? Views on warfare from the United States Armed Forces perspective, https://www.doria.fi/bitstream/handle/10024/74215/E4081_HuovinenKPO EUK63.pdf? sequence=1, (April 2011).

12. Emanuel Peterliceanu, Războiul hibrid - noua ameninţare la adresa stabilităţii globale, General Philip Breedlove, the military commandant of NATO said "Use by Russian troops without uniform, the so-called «little green men» and perhaps the most startling information in blitzkrieg that we saw in the information war history, was part of the first Russian assault in Ukraine". "What we see in Russia, now, in this hybrid approach of war is that they are using all the tools we have, to agitate, then begin to exploit them through their military equipment", 17.09.2014, http://www.ifz.ro/razboiul-hibrid-noua-amenintarela-adresa-stabilitatii-globale/html, (accessed April 5, 2015.

13. Ce este "războiul hibrid" dus de Rusia în Ucraina şi cum a fost el pregătit de zece ani sub ochii permisivi ai Occidentului, $1^{\text {st }}$ of September 2014, http://www.hotnews.ro/stiriinternational-18014446-este-razboiul-hibrid-dus-rusia-ucraina-cum-fost-pregatit-zeceani-sub-ochii-permisivi-occidentului.htm, (accessed January 5, 2014).

14. Article The "Gerasimov Doctrine" and Russian Non-Linear War, https://inmoscowsshadows. wordpress.com/2014/07/06/the-gerasimov-doctrine-and-russian-non-linear-war/ and article Ukraine: Russia's new art of war, by Sam Jones, http://www.ft.com/cms/s/2/ea5e $82 \mathrm{fa}-$ 2e0c-11e4-b760-00144feabdc0.html\#axzz3VFP2i8bD, (accessed April 3, 2015.

15. Article Vald Ilina, Traian Basescu se teme de invazia omuleţilor verzi ai ruşilor în presa românească , 14.09.2014, "I fear most the little green men before the little green men with rifles. Basescu's statement refers to a possible appearance in Romania of 'elements' in the media to spread Kremlin propaganda in our country. In his statement to the Summit talked about hybrid war. It is a war of 'little green men' and you're watching the film in Ukraine you will see that the first media war began, followed destabilization inside and then it came to armed little green men", http://www.paginaeuropeana.ro/traian-basescuse-teme-de-invazia-omuletilor-verzi-ai-rusilor-in-presa-romaneasca/, (accessed April 2, 2015).

16. Article Definiţii pentru conflictul din regiunile estice ale Ucrainei, 04.04.2015, http://www.europalibera.org/content/article/25424205.html. Moldovan analyst Igor Botan said: "We, people from Republic of Moldova know and in particular those who have followed the unfolding of the Transnistrian conflict, we see that things are drawn as indigo: the same civil war, the central charges of war against its own people, with all arsenal participants coming from Russian Federation allegedly are individuals and so on. But after more than 20 years I think in this post-Soviet space I learned that real goals and how you plan to achieve these goals". 
17. Case concerning the military and paramilitary activities in and against Nicaragua (Nicaragua $v$. United States of America) (merits) judgement of $27^{\text {th }}$ of June 1986, http://www.icjcij.org/docket/?sum=367\&p1=3\&p2=3\&case=70\&p3=5, (accessed April 4, 2015).

18. For details see: Nicaragua Vs United States (Summary) On Self Defence And Use Of Force, https://ruwanthikagunaratne.wordpress.com/ 2012/11/15/nicaragua-vs-us-casesummary/, (accessed April 6, 2015).

19. Gheorghe Văduva, "Impactul geopolitic al summit-ului NATO din Țara Galilor pe axa Marea Neagră - Marea Baltică", Univers strategic, Anul V, nr. 4(20), (2014): 9-23.

20. Article Ce este "războiul hibrid" dus de Rusia în Ucraina şi cum a fost el pregătit de zece ani sub ochii permisivi ai Occidentului, 01.09.2014, http://www.hotnews.ro/stiriinternational-18014446-este-razboiul-hibrid-dus-rusia-ucraina-cum-fost-pregatit-zeceani-sub-ochii-permisivi-occidentului.htm, (accessed April 3, 2015).

21. Article Războiul hibrid şi braţul său nevăzut: spionajul, 23.03.2015, http://www.etransmedia.ro/ razboiul_hibrid_si bratul_sau_nevazut spionajul-4772, (accessed April 2, 2015).

22. Ibidem.

23. "Se apropie cel de-al Treilea Război Mondial”, Publika MD, 04.02.2015, http://www.publika.md/expert-militar-rus--se-apropie-cel-de-al-treilea-razboimondial 2225991.html, (accessed March 30, 2015).

24. Germania îşi schimbă strategia militară pentru a face faţă războiului hibrid folosit de Rusia, $18^{\text {th }}$ of February 2015, http://adevarul.ro/international/europa/ germania-isischimba-strategia-militara-fata-razboiului-hibrid-folosit-rusia1 54e4ac27448e03c0fdbe1bc5/index.html, (accessed April 18, 2015).

25. Robert A. Newson, "Why the US Needs a Strategy To Counter "Hybrid Warfare" October 23, 2014, http://www.defenseone.com/ideas/ 2014/10/why-us-needs-strategycounter-hybrid-warfare/97259/, or Ioana Ivan, "Războiul hibrid, o provocare pentru armata americană”, 26.11.2014, http://incomemagazine.ro/articole/razboiul-hibrid-oprovocare-pentru-armata-americana, (accesate March 30, 2015).

26. Paul Ciocoiu, "Efectul manevrelor agresive ale Rusiei în Marea Baltică: Suedia şi Finlanda vor o forţă navală comună", 18.02.2015, http://www.evz.ro/efectulrusia.html, (accessed March 29, 2015).

27. Simona Mătieş, "Serviciile secrete britanice angajează spioni vorbitori de limba rusă, care să stea cu ochii pe Putin", 17.02.2015, http://www.evz.ro/serviciile-secretebritanice-angajeaza-spioni-vorbitori-de-limba-rusa-care-sa-stea-cu-ochii-pe-putin.html, (accessed March 22, 2015).

28. Decret semnat: Rusia angajează mercenari!, 04.01.2015, http://www.digi24.ro/Stiri/ Digi24/Extern/Stiri/rusia+mercenari+armata, (accessed March 3, 2015).

29. Raluca Joiţa, "Top 10 - Cele mai mari forţe militare din lume", 19.04.2014, http://media.imopedia.ro/stiri-imobiliare/top-10-cele-mai-mari-forte-militare-din-lume22334.html, (accessed March 5, 2015).

30. Mihai Drăghici, "Rusia va avea 50 de nave şi submarine suplimentare în 2015. Unele ar putea ajunge în Marea Neagră", http://www.mediafax.ro/externe/rusia-va-avea-50-denave-si-submarine-suplimentare-in-2015-unele-ar-putea-ajunge-in-marea-neagra13920931, (accessed March 15, 2015).

31. Director of Center for Political-Military Studies in Moscow.

32. "Rusia avertizează România", http://www.digi24.ro/Stiri/Digi24/Extern/Europa/ Rusia+avertizeaza +Romania, 32. $1^{\text {th }}$ of February 2015 and "Ruşii, deranjaţi de apropierea structurilor NATO de graniţele lor. Avertisment la adresa României”, $9^{\text {th }}$ of February 2015, http://stiri.tvr.ro/rusii--deranjati-de-apropierea-structurilor-nato-degranitele-lor--avertisment-la-adresa-romaniei_56370.html, (accessed March 15, 2015). 
33. The current situation will inevitably lead to the outbreak of World War III. This is the opinion Vernochet Jean-Michel, a French writer, political analyst, journalist, specialist in conspiracy theories and an expert in the Middle East and Russia. More details on: http://romanian.ruvr.ru/2014 07 01/Al-Treilea-Razboi-Mondial-la-orizont-7404/.

34. "Presa rusă pretinde ca în Ucraina a început al Treilea Război Mondial", http://www.ziare.com/international/ucraina/presa-rusa-pretinde-ca-in-ucraina-a-inceputal-treilea-razboi-mondial-1326741, (accessed April 5, 2015).

35. Collocation available online at: http://www.rightwords.ro/citate/nu-stiu-cu-ce-arme-va-filuptat-cel-de-al-treilea-razboi--17119, (accessed April 5, 2015).

\section{Bibliography}

***Actul final al Conferinţei pentru Securitate şi Cooperare in Europa, elaborat la Helsinki la 1 august 1975;

Dughin, A., Bazele geopoliticii şi viitorul geopolitic al Rusiei. Bucharest: Eurasia Publishing House, 2011.

McCuen, John J., "Hybrid Wars". Military Review, (March-April 2008).

Onica, Jarka, Beatrice. Drept internaţional umanitar - Note de curs. Bucharest: Universul Juridic Publishing House, 2010.

Parkes, R., A. Sobják. "Understanding EU Action during "Euromaidan": Lessons for the Next Phase". Strategic File, 5(41), (February 2014).

www.smallwarsjournal.com

http://www.globalpolicyjournal.com/blog/05/03/2013/what-if-hybrid-warfarethreat-conceptwas-simply-meant-make-us-think

http://www.defenseone.com/ideas/2014/10/why-us-needs-strategy-counter-hybridwarfare/97259/

http://www.europeanleadershipnetwork.org/can-hybrid-war-become-the-main-securitychallenge-for-eastern-europe_2025.html

http://www.ifz.ro/social/razboiul-hibrid-noua-amenintare-la-adresa-stabilitatii-globale.html; https://jurisdictie.wordpress.com/2013/12/02/statutul-curtii-internationale-de-justitie-inlimba-romana/

https://www.icrc.org/eng/assets/files/other/rom-irrc 857 henckaerts.pdf

https://www.icrc.org/eng/assets/files/other/irrc 850 stewart.pdf

http://www.ifz.ro/razboiul-hibrid-noua-amenintare-la-adresa-stabilitatii-globale/html

***https://inmoscowsshadows.wordpress.com/2014/07/06/the-gerasimov-doctrine-andrussian-non-linear-war/

http://smallwarsjournal.com/blog/journal/docs-temp/188-glenn.pdf

http://www.gao.gov/assets/100/97054.html

https://www.doria.fi/bitstream/handle/10024/74215/E4081_HuovinenKPO_EUK63.pdf?sequ ence $=1$

https://ruwanthikagunaratne.wordpress.com/2012/11/15/nicaragua-vs-us-case-summary/ 